\title{
SPATIOTEMPORAL BIOACCUMULATION OF LEAD, CADMIUM, ZINC AND COPPER METALS IN LETTUCE SEA Ulva lactuca HARVEST IN TWO ALGERIAN WEST COASTS
}

\author{
LINDA ABI-AYAD ${ }^{1}$,SIDI-MOHAMMEDBAHAE-DDINEGHEZLAOUI ${ }^{2 *}$,NASSEREDDINE \\ BELKHOUCHE $^{1}$, JOSÉ MORILLO AGUADO ${ }^{3}$
}

${ }^{1}$ Laboratory of Separation and Purification Technologies, Faculty of Sciences, Department of Chemistry, Box 119, University of Tlemcen, Algeria

${ }^{2}$ Laboratory of Management of the Naturals Ecosystems, Faculty of Nature and life Sciences, and Earth and the Universe Sciences, Department of Agronomy, Box 119, University of Tlemcen, Algeria; e-mail:ghezlaouibahae@gmail.com ${ }^{3}$ Departments of Chemical Engineering and Environment, High Technical School of Engineering, University of Seville, Spain

* Author for correspondence

\begin{abstract}
Abi-Ayad L., Ghezlaoui S.-M. B.-D., Belkhouche N., Aguado J.M.: Spatiotemporal bioaccumulation of lead, cadmium, zinc and copper metals in Lettuce Sea Ulva lactuca harvest in two Algerian west coasts. Ekológia (Bratislava), Vol. 37, No. 3, p. 243-258, 2018.

This work brings an evaluation of the quality of littoral zone of Algerian in two neighbouring port coasts, namely, Honaine and Beni Saf, chosen as significant discharge sites. This was followed by a comparison of the state of these coasts with those of the Mediterranean coastal areas. The study was conducted in all seasons in the year 2011-2012 by measuring the hydrological physicochemical parameters ( $\mathrm{pH}$, temperature, turbidity and salinity) and using sea lettuce Ulva lactuca as significant 'biomarker of the quantity of metal contaminants ( $\mathrm{Cd}, \mathrm{Pb}, \mathrm{Cu}$ and $\mathrm{Zn})$ '. Harvesting of Ulva and the seawater samples were performed in each season in three stations, characterised by discharges of waste and industrial water and saline discharges from the recent installation of desalination in Honaine. The metal concentrations in seawater showed significant variations between stations and the harvest season, resulting in the appearance of pollution of $\mathrm{Cd}, \mathrm{Pb}, \mathrm{Cu}$ and Zn. Also this result was manifested in Ulva in the station S1 (Beni Saf) and S2 (Honaine-beach) with the exception of copper. These results have exceeded tolerable international standards.
\end{abstract}

Key words: pollution, bio-indicator, metal, algae, Algeria.

\section{Introduction}

In recent years, the dispersion of metal contaminants in Mediterranean areas (western Algeria) is constantly evolving (Taleb, Boutiba, 2007). This phenomenon increases through the increase in harbours' pollution of urban and industrial (oil waste) origin (Pastor et al., 1994). 
At present, the marine heritage protection presents a huge challenge for the industrial and scientific communities on both the economical and ecological plans.

The Algerian coast encompasses a wide range of habitats and marine biodiversity, that said, it is considered amongst the highest in the Mediterranean, bringing together the marine species of flora and fauna such as green algae (Ulva lactuca, U. fasciatus and Enteromorpha linza) and red algae (Corallina officinalis and Polygavernosa dentata). They have the distinction of establishing the balance of the aquatic ecosystem and are good indicators of environmentally health; it is also the case of the brown seaweed Cystoseira, which was used in the control of the arsenic, chromium, cadmium and cobalt in the Syrian coast (Nakhlé, 2003). The role of algae in structuring communities of the rocky substrates is well known.

The habitat of these species is characterised by inputs of the pollutants of the agglomerations. This is, in the Algerian coast, that research on these species that are rare and limited to the prospections. For this, we have undertaken eco-biological studies on a particular type of seaweed Ulva in the North Shore (Beni Saf, Honaine, etc.), based on its distribution and exposure to pollution to heavy metals.

We found that the species is highly vulnerable to metal contaminants according to the results of previous work (Munda, Hudnik, 1991). The deposit and bioaccumulation of heavy metals in algae is very observable. This has been demonstrated in numerous studies in various Mediterranean regions (Bryan, Hummestrone, 1973). That said, the choice focused on these algae is related to their richness in vitamins and trace elements and have therapeutic characteristics indispensable to man, which is necessary to protect them.

These algae were used a long time ago, as part of the traditional diet of coastal communities, but they are part until today in many countries. Their nutrition is made by marine plants, nearly a 3,589,729 t; algae are used for obtaining original chemicals (phycocolloids) that are capable of gelling or thickening aqueous solutions (3.28322 million $t$ ). Both these uses have grown steadily since the beginning of the century and, currently, require more than $6,873,949 \mathrm{t}$ of marine plants (fresh weight) per year or $90 \%$ of total production $(7637721 \mathrm{t}$ ) in 1994 (Perez, 1997).

Furthermore, this allowed the classification of marine green chlorophylliens in Europe, of order food of which were took, Fucus vesiculosus, Himanthalia elongata (Sea Bean or seafood spaghetti), Ascophyllum nodosum and Undaria pinnatifida (sea fern) are in the first position; Palmaria palmata, Laver, Chondrus crispus (lichen) and Verrucosus gracilaria (ogo-nori) are in the second position; the lettuce Ulva lactuca seas and Enteromorpha sp. are in the third position and Spirulina sp. (spirulina) is in the fourth position (Perez, 1997). The recent interest on these Ulva is very interesting; given their beneficial virtues, dietetic food is sold in the market in various forms, dried leaves, glitter and granules in powder, whose residents gather around 40-45 t fresh U. lactuca (32 t), Enteromorpha sp. (1 t) and so on. Still widely consumed in East Asia and particularly in Japan, China and Korea, their use remains limited in Europe, that said, the first attempts to introduce the marine plants in the Western diet actually date from the fifteenth century. In time, they had the aim to soften the famines that struck episodically the coastal populations (Munda, Hudnik, 1991).

In the recent years, the consumption of food plants made a new appearance in the European zone, such as France, Belgium, and Germany. She corresponds at the request of the 
immigrant Asian colonies, a gastronome, seeking diversity and the people wishing to guard against cardiovascular diseases, a diet low in fat. Much of this demand is met by imports from the Far East. In the United States, aquatic plants are mainly used as ingredients, spices or seasoning, the control of which is necessary to care, relating only to heavy metals and radioactivity levels. Japan has no standards for these productions but very demanding for imported marine plants (Perez, 1997)

The importance of the nutritional value of algae, and some interest on these health benefits arouse recently. The time has come to take stock of the issue.

It is in this context that the protection of aquatic chlorophylls remains essential to preserve the trophic balance of marine ecosystems. In addition, green algae are an excellent source of fibre, minerals and phytonutrients (MacArtain et al., 2007). They are safe for health, although they have to pay attention to certain varieties because of their high content of sodium, iodine and heavy metals (Cheggour et al., 2001). In addition, our concern has become major, facing the bioaccumulation of toxic metals in algae, including $\mathrm{Pb}, \mathrm{Cu}, \mathrm{Cd}, \mathrm{Zn}$ and so on, which can lead to their disappearance over the years. The bioaccumulation of toxic metals impacts on marine heritage and causes deterioration of fish and shellfish production, thereby reducing fishing activities that are of economic interest to many countries.

The coastal region of Beni Saf is located on the northwest coast of Algeria, $67 \mathrm{~km}$ from the city of Tlemcen (see Fig. 1). Then the Coast of Honaine is halfway between Ghazaouet and Beni Saf. The city of Beni Saf, populated by 42,000 habitants (Leynaud, 1968), is marked by beaches that attract a considerable flow of summer visitors. The port area that was the second fishing port with an average production of $5000 \mathrm{t} /$ year (W.H.O, 1987) today demonstrated a true fall, to the point of some fishes (red grouper, etc.) have become rare. This area includes industrial activities (cement) and maritime traffic. Nevertheless, the area of Honaine (Fig. 1), populated by 5,408 habitants (Leynaud, 1968), reveals an urban and artisanal fishing activities, which is moderately developed compared to Beni Saf, and has just been equipped by the desalination plant. This can cause a potential pollution by saline discharges. The presence of toxic metals from different discharges may increase the degradation of these areas (Taleb, Boutiba, 2007).

The aim of the present work is to carry out a comparative study on the nature and the level of pollution of the two port areas, Beni Saf and Honaine. This will be carried out according to the spatial and temporal assessment of the quality of seawater and bioaccumulation of toxic metals in green algae $\mathrm{U}$. lactuca. These toxic metals are $\mathrm{Pb}, \mathrm{Cd}, \mathrm{Cu}$ and $\mathrm{Zn}$, which come from different discharges in the middle. And those to determine the possible transfer of pollution between the areas had taken into consideration that may prejudice for sea lettuce.

\section{Material and methods}

The sea lettuce U. lactuca was seasonally collected during the period 2011-2012, at the stations shown in Fig. 1.The choice of stations (S) was based on the presence of bio-indicators (Ulva) in the vicinity of wastewater effluents (collectors, $\mathrm{C}$ ), in order to assess their impact on the receiving marine environment to determine the bioaccumulation threshold of metallic pollutants in the species.

The description and nature of wastewater outfalls are summarised as follows:

- $\quad$ - C1 (Beni Saf): Collector receiving a mixture of urban and industrial wastewater (cement plant, shipping traffic and fishing); 
- $\quad$ C2 (Honaine; beach): Collector receiving a mixture of urban wastewater from the village of Ouled Youcef;

- $\quad$ C3 (Honaine, port): Collector receiving a mixture of wastewater (artisanal fisheries).

\section{Sampling stations}

The sampling stations are as follows:

- S1: the beach and port of Beni Saf, next to collector C1;

- $\quad$ S2:the beach of Honaine Bay, next to collector C2;

- S3:the port of Honaine Bay, next to collector C3.

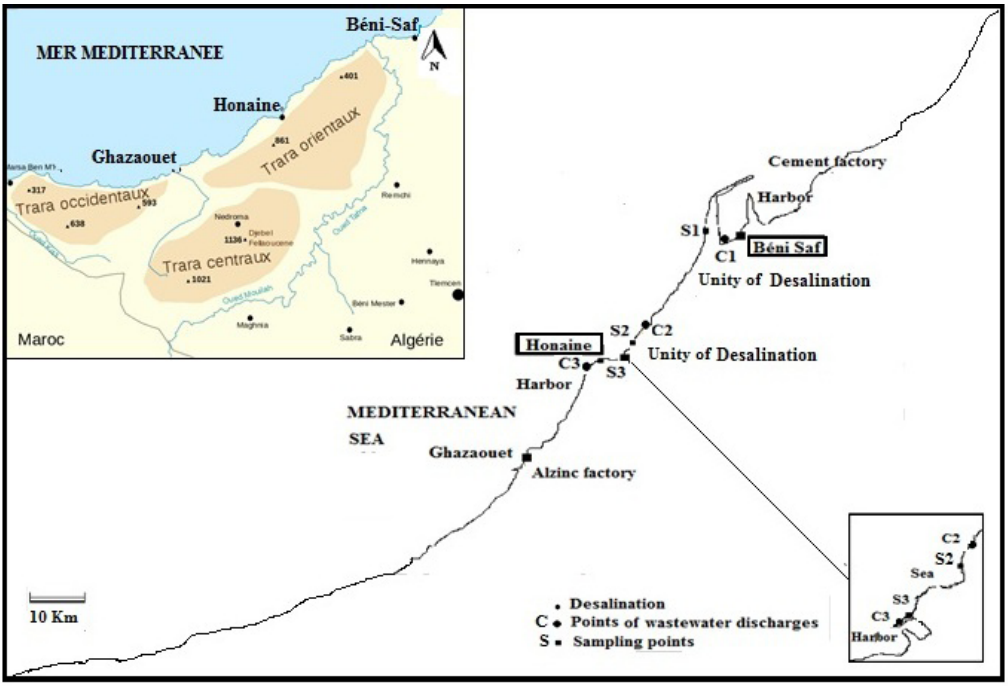

Fig.1. Localisation of sampling sites of sea lettuce along the coasts of Beni Saf and Honaine.

\section{Sample collection and sampling}

Samples of seawater and Ulva were collected at the following three sampling points: first (01) sampling point is on the separating line between the beach of Beni Saf and its harbour (S1), second and third (02) sampling points are in the area of Honaine, one in the vicinity of the beach (S2) and the other in the harbour (S3). Marine water samples were collected during the period 2011-2012, according to Aminot and Chaussepied protocol (1983). Measurements of some physicochemical factors, such as $\mathrm{pH}$, electrical conductivity, air-water temperature and salinity, were made in situ.

\section{Ulva}

Samples of green algae were harvested by hand before being transported to the laboratory in sachets, rinsed with water, ultra-filtered (Millipore) to remove the external impurities and then dried in air. For each sample, we also weighed $1 \mathrm{~g}$ of previously ground seaweed and filtered using a sieve ( $63 \mu \mathrm{m}$ in diameter). They were placed in Teflon beakers, in which we added $5 \mathrm{ml}$ of $60 \%$ of perchloric acid, $\mathrm{HClO}_{4}$, and we left the sample for $1 \mathrm{~h}$ at $80^{\circ} \mathrm{C}$ on a hot plate under a host. After almost total evaporation, we added, $3 \mathrm{ml}$ of $\mathrm{HCl}$ (hydrochloric acid) and $1 \mathrm{ml} \mathrm{HNO}_{3}$ (nitric acid) to water region. The reaction is always carried out hot at $80^{\circ} \mathrm{C}$ to remove all the solid fractions. When all the 
solid fractions have disappeared, we again evaporated the excess acid. Finally, we introduced $5 \mathrm{ml}$ of doubly distilled water to solubilise the metals (the duration of this step is $2 \mathrm{~h}$ at $80^{\circ} \mathrm{C}$ ). The rest was the adjusted at $20 \mathrm{ml}$ of solution bidistilled, filtered using a filter paper and then stored in boxes in a refrigerator. At the end, the digests are led to the assay for quantification of metals by the spectrophotometric atomic absorption.

\section{Analytics instruments}

Sea water: The levels of metals, such as $\mathrm{Pb}, \mathrm{Cu}, \mathrm{Cd}$ and $\mathrm{Zn}$, in seawater was determined using the Aurora Trace AI 1200 - Atomic Absorption Spectrometer supplied with an acetylene torch (Laboratory of Alzinc plant, Ghazaouet). Some physico-chemical characteristics of seawater, such as the conductivity, were determined by a Tetracon 325 conductimeter, whilst $\mathrm{pH}$ measurements were made using a Box 389 type $\mathrm{pH}$ meter, and the turbidity was measured with a Hach 2100 turbid meter.

Sea Lettuce: The levels of $\mathrm{Pb}, \mathrm{Cu}, \mathrm{Cd}$ and $\mathrm{Zn}$ in Ulva samples was determined using the Perkin Elmer 4110 Atomic Absorption model ZL (THGA), in (Seville-Spain).

\section{Analytic performances}

The limits of detection (LODs) of heavy metals, such as $\mathrm{Pb}, \mathrm{Cu}, \mathrm{Cd}$ and $\mathrm{Zn}$, for the dosage of seawater samples were determined by Flame Atomic Absorption Spectrometry and assayed in ppm (Table 1).

\section{Limits of detection}

The LODs were calculated relative to the standard deviation and reported to the arithmetic mean value. They are given in Tables 1 and 2, respectively, for seawater and Ulva.

T a b l e 1. Limits of detection of seawater by Flame Atomic Absorption Spectrometry.

\begin{tabular}{|l|c|c|c|c|}
\hline & Cd & Cu & Pb & Zn \\
\hline LOD $(\mathrm{ppm})$ & 0.03 & 0.05 & 0.10 & 0.05 \\
\hline
\end{tabular}

$\mathrm{T} \mathrm{a} \mathrm{b} \mathrm{l} \mathrm{e} \mathrm{2.} \mathrm{Limits} \mathrm{of} \mathrm{detection} \mathrm{of} \mathrm{Ulva} \mathrm{by} \mathrm{Flame} \mathrm{Atomic} \mathrm{Absorption} \mathrm{Spectrometry.}$

\begin{tabular}{|l|c|c|c|c|}
\hline & Cd & Cu & Pb & Zn \\
\hline LOD $(\mathrm{ppb})$ & 0.05 & 0.60 & 0.30 & 2 \\
\hline
\end{tabular}

\section{Precision}

The accuracy of measurements was evaluated based on the results of certified assayed samples from the Chemical and Environmental Engineering Department for Ulva in Seville (Spain).

\section{Statistical treatment}

The statistical analysis of the data was performed using the software STATISTICA (Statsoft Version 6.1.478.0) for calculating the two-factor analysis of variance (ANOVA) (sites, seasons), on seasonal concentrations of heavy metals in $U l v a(\mathrm{mg} / \mathrm{kg}$ dry weight). Data are presented as the mean \pm standard error. ANOVA was used to compare means of concentrations of heavy metals between stations; when ANOVA was significant $(\mathrm{p}<0.05)$, post-hoc comparison of means was performed using Duncan's test. Statistical analysis was performed using the software STATISTICA (Statsoft STATISTICA version 6.1.478.0).

The horizontal line in each figure shows the average value of references for each metal element by Food and Agriculture Organization of the United Nations F.A.O (1994). 
The two fundamental climatic factors, namely, temperature and precipitation, were taken into consideration. These factors affect the state of the marine biotope, and particularly algae, such as Ulva (Poggi, 1990). Rainfall affects the quality of sea water, particularly the increase or decrease in water intakes (minerals), water regeneration and ecological phenomena that can take place. In coastal environments, some industrial discharges and stormwater lead to $\mathrm{pH}$ change, which in this case turns out to be a pollution index. However, this change remains much localised both in time and in space, because of the buffering capacity of sea water (Aminot, Chausssepied, 1983). On the other hand, the temperature of water plays a critical role in the functioning of coastal ecosystems, which have significant ecological repercussions (Leynaud, 1968). Water temperature acts on the density, viscosity, gas solubility in water, dissociation of dissolved salts as well as the chemical and biochemical reactions and development and growth of living organisms in water, particularly microorganisms (Leynaud, 1968).

Northern Algeria has a Mediterranean climate, which is characterised by hot, dry summers and cool, wet winters. Therefore, two climatic parameters, that is, temperature and rainfall, were considered in order to determine the climate in the areas under study, namely, Beni Saf and Honaine.

The climatic factors were assessed based on the data from Beni Saf and Honaine weather stations. The data were collected for a period of 10 years (2003-2012). The obtained results were used to plot the ombrothermic diagram (Bagnouls, Gaussen, 1953) (Figs 2a,b). From there, it was found that the region of Honaine has a Mediterranean climate with an average annual rainfall of about 350-400 mm. The wettest period extends from November to April with a maximum of $80 \%$. This area has around 20 days of mist. In winter, the average temperature oscillates around $10^{\circ} \mathrm{C}$, with a minimum of $6^{\circ} \mathrm{C}$. There is neither frost nor any significant humidity in the air, because of the influence of the sea. By cons, in summer, the average annual temperatures oscillate around $26^{\circ} \mathrm{C}$. East-Northeast and WestSouthwest winds prevail in this area (W.H.O, 1987).

The climate in Beni Saf is similar to that of Honaine. The average winter temperature hovers around $15^{\circ} \mathrm{C}$, with a minimum of $8{ }^{\circ} \mathrm{C}$. The average summer annual temperatures oscillate around $26^{\circ} \mathrm{C}$, with a maximum of $40{ }^{\circ} \mathrm{C}$. Calculations show that Emberger's pluviothermic ratio $(\mathrm{Q})$ in the area of Beni Saf is 58.12, whilst that in Honaine is 40.41. Consequently, the climate prevailing in the two areas is semi-arid thermotype, which is characteristic of the climate on the Mediterranean coast.
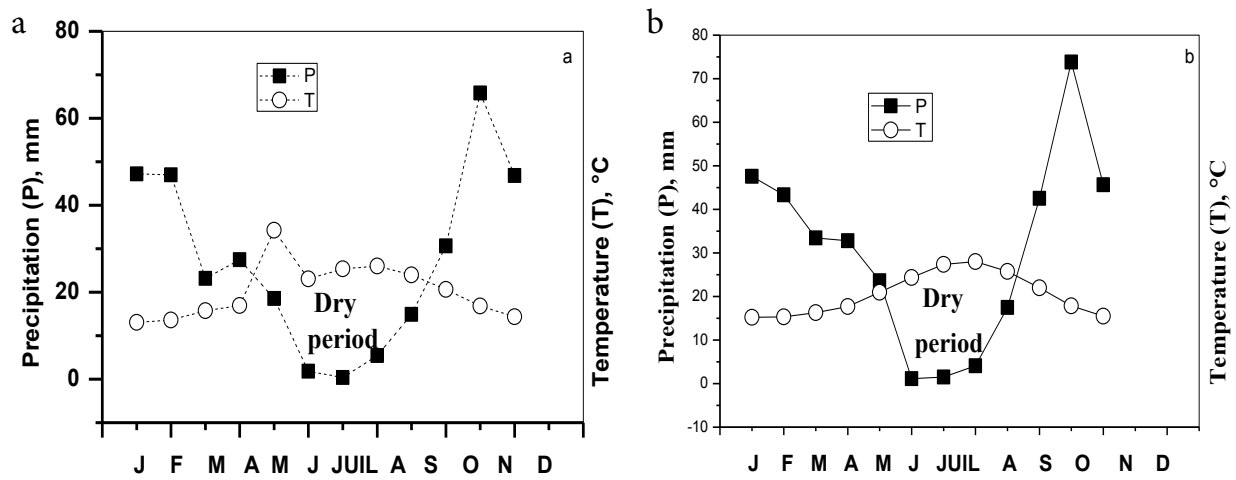

Fig. 2. Ombrothermic diagram of Bagnoul and Gaussen: (a) area of Beni Saf; (b) area of Honaine.

\section{Results and discussion}

Sea water features on the coasts of the towns of Beni Saf and Honaine, during the period 2011-2012, are given for the three stations in Table 3. 
T a b l e 3. Average characteristics of seawater in the towns of Beni Saf and Honaine, during the period (2011-2012), in all three stations, S1, S2 and S3. The results are expressed as mean \pm SE, limit values are in brackets (SE: standard errors).

\begin{tabular}{|l|c|c|c|c|c|}
\hline Stations & $\mathbf{p H}$ & Salinity $(\mathbf{\%})$ & $\begin{array}{c}\text { Conductivity } \\
(\boldsymbol{\mu S} / \mathbf{c m})\end{array}$ & $\begin{array}{c}\mathbf{T}_{\text {Eau }} \\
\left({ }^{\circ} \mathbf{C}\right)\end{array}$ & $\begin{array}{c}\text { NTH (turbidity) } \\
(\mathbf{m g} / \mathbf{l})\end{array}$ \\
\hline \multirow{2}{*}{ S1 } & $7.13-7.34$ & $29.8-37.1$ & $46.1-55.7$ & $26-24.2$ & $0.301-0.557$ \\
& $7.2 \pm 0.09$ & $32.23 \pm 3.44$ & $49.3 \pm 4.54$ & $25.4 \pm 0.84$ & $0.386 \pm 0.01$ \\
\hline \multirow{2}{*}{ S2 } & $7.25-8.11$ & $25-37$ & $50-55.7$ & $24.3-29$ & $0.203-0.854$ \\
& $7.54 \pm 0.33$ & $29 \pm 0.47$ & $51.9 \pm 2.68$ & $25.86 \pm 2.21$ & $0.42 \pm 0.025$ \\
\hline \multirow{2}{*}{ S3 } & $7.33-8.03$ & $36.3-37.1$ & $54.8-55.9$ & $24.4-25$ & $0.143-0.383$ \\
& $7.56 \pm 0.27$ & $36.57 \pm 0.37$ & $55.17 \pm 0.51$ & $24.6 \pm 0.28$ & $0.223 \pm 0.009$ \\
\hline
\end{tabular}

The physicochemical parameters of seawater recorded during the four seasons provide information about the status of the quality of marine water in the coastal areas of Beni Saf and Honaine.

The observed values indicate that the $\mathrm{pH}$ is more or less neutral in the three stations, both in wet and dry seasons. Indeed, the average $\mathrm{pH}$ value in both stations ( $\mathrm{S} 1$ and $\mathrm{S} 3$ ), which receive urban and industrial discharges, is 7.38 . This is less than 8 , which indicates a slight acidic environment. However, this $\mathrm{pH}$ value remains in the recommended Algerian Standards in the case of discharges in the receiving environment (J.O.R.A, 2006).

Turbidity measurement in the three study sites showed different values, which are less than 5. This is in good agreement with the standards (O.I.E, 2009). These results were predictable, as the expertise is found to be consistent with clear surface waters. The annual salinity at the three stations ranges from 29 to $36.57 \%$. These values are within the standard range, which limits the concentrations between 35 and 39\% (Huppatzet, 1987). The salinity in closed or isolated seas may be different from that in the great oceans. The lowest average value was recorded at station S2, which is located near collector C2 (beach of Honaine). In addition, the salinity may change during the year, depending on the season. Seawater conductivity is subject to significant variations, depending on temperature and salinity. The obtained conductivities range from 49.3 to $55.17 \mu \mathrm{sm}^{-1}$. This last value was found in station S3, next to collector C3 (wastewater from craft activities). However, these results remain within the standards, as the electrical conductivity extends between 40 and $53 \mu \mathrm{s}$ $\mathrm{cm}^{-1}$, at the temperature of $25^{\circ} \mathrm{C}$ (Marcet, 1919).

Temperature plays a role in the phenomenon of photosynthesis, which is responsible for the species multiplication (algae). Temperature is very important for the solubility of salts, and especially of gases. It also influences the $\mathrm{pH}$. The median value, between 7 and $25{ }^{\circ} \mathrm{C}$, corresponds to a neutral solution (De Villers et al., 2005). Temperature also allows correcting the analysis parameters because their values depend on it (conductivity). Furthermore, by highlighting the contrasts of water temperature in a medium, it is possible to obtain information on the source and the flow of water (Rodier, 1984). The temperatures of seawater, in the three stations, vary between 24.60 and $25.86^{\circ} \mathrm{C}$. These ambient temperatures, which are in agreement with the Algerian discharge standards (J.O.R.A, 2006) correspond to the meteorological conditions at the moment of sampling. 


\section{Metal contents in seawater}

Levels of heavy metals in seawater are calculated for the three stations and presented in Table 4.

$\mathrm{T}$ a b 1 e 4. Variations in heavy metals concentrations $(\mathrm{mg} / \mathrm{kg})$ of seawater in the littoral of Beni Saf and Honaine harbour, during the period (2011-2012) in all three stations S1, S2 and S3. The results are expressed as mean \pm SE, limit values are in brackets (SE: standard errors).

\begin{tabular}{|l|c|c|c|c|}
\hline & Cd & Pb & Cu & Zn \\
\hline \multirow{2}{*}{ S1 } & $0.071-0.86$ & $0.49-0.65$ & $0.025-0.58$ & $0-4.25$ \\
& $0.33 \pm 0.03$ & $0.54 \pm 0.01$ & $0.21 \pm 0.02$ & $1.42 \pm 0.16$ \\
\hline \multirow{2}{*}{ S2 } & $0.022-0.25$ & $0.016-0.69$ & $0.058-0.083$ & $0-0.35$ \\
& $0.098 \pm 0.01$ & $0.24 \pm 0.02$ & $0.066 \pm 0.01$ & $0.12 \pm 0.01$ \\
\hline \multirow{2}{*}{ S3 } & $0.056-0.11$ & $0.35-0.70$ & $0.079-0.088$ & $0-7.67$ \\
& $0.074 \pm 0.001$ & $0.47 \pm 0.01$ & $0.082 \pm 0.01$ & $2.56 \pm 0.30$ \\
\hline
\end{tabular}

\section{Cadmium}

The observed seasonal concentrations reveal significant levels of cadmium in the three stations. The highest content was found to be equal to $0.86 \mathrm{ppm}$ in the season of autumn at station S1 in the coastal area of Beni Saf. The average annual level of cadmium was $0.33 \mathrm{ppm}$. This is alarming with regard to the quality of the environment, because cadmium content exceeds the standards of the Mediterranean coastal areas, recommended by FAO, which suggests a minimum level equal to $0.01 \times 10^{-3} \mathrm{ppm}(\mathrm{FAO}, 1994)$ (Martin, Whitfield, 1983). This is due to urban and industrial waste (cement plant, shipping and fishing) that are discharged by collector C1, which is located near station S1. A similar result was found on the Atlantic coast of southern Spain (Usero et al., 2003). Indeed, the recorded cadmium levels remain tolerable compared to the discharge standards in a receiving environment, as defined by the Algerian regulations (contents of the order of $3 \mathrm{mg} / \mathrm{l})$.

\section{Lead}

Seasonal evaluation of lead in seawater indicates very high levels in the three stations throughout the year. The highest value, that is $0.7 \mathrm{ppm}$, was observed in station S3 (port of Honaine), in the spring season, whilst the annual average content is $0.54 \mathrm{ppm}$. This figure is much higher than $0.03 \times 10^{-3} \mathrm{ppm}$, which is the threshold required by the FAO (Martin, Whitfield, 1983), and $0.5 \mathrm{ppm}$, which is the value requested by the Algerian regulations (J.O.R.A, 2006). Regarding the annual variations of lead, the content at station S1 exceeds the Algerian discharge standards in a receiving environment. Therefore, it is easy to note that the area of Beni Saf (S1) is lead contaminated. The hypothesis of lead contamination resulting from discharges at collector $\mathrm{C} 1$ remains valid, just like before. These results are in good agreement with those found in previous works (Usero et al., 2003). 


\section{Copper}

Seasonal copper levels were found at values that exceed the standards of the Mediterranean coastal waters (FAO); they were above the threshold limit of $0.001 \mathrm{ppm}$ (Martin, Whitfield, 1983 ) in all three stations. Indeed, an annual average content of $0.21 \mathrm{ppm}$ was found at station S1. Copper pollution is probably due to discharges at collector C1 (Usero et al., 2003).

Previous works related to the presence of copper dispersed along the Atlantic coast of southern Spain showed similar findings. On the other hand, the annual average remains below the Algerian discharge standards in the receiving environment, where the limit value is 0.5 ppm (Usero et al., 2003).

\section{Zinc}

Zinc concentrations were high in the three stations during all seasons, except in summer. They were found much higher than the threshold limit, which is $2.5 \times 10^{-3} \mathrm{ppm}$, as defined by FAO (Martin, Whitfield, 1983). In autumn, a significant value equal to $7.67 \mathrm{ppm}$ was recorded at station S3 (port of Honaine). However, the annual average content was $2.56 \mathrm{ppm}$. Station S1 presented a zinc peak in winter, with a concentration equal to $4.25 \mathrm{ppm}$. This reflects the pollution degree in the port area of Beni Saf, because of urban and industrial discharges from collector C1. However, the contamination of the port area of Honaine (S3) is due to discharges from collector C3, which probably receives zinc effluents from the Zinc Production Plant (Al-Zinc). This finding about pollution is similar to that given previously, concerning seawater along the Atlantic coast of southern Spain (Usero et al., 2003). Compared to the Algerian standards, which define a threshold limit of $0.5 \mathrm{ppm}$, the pollution situation is still maintained (J.O.R.A, 2006).

In conclusion, the gradient of annual accumulation of heavy metals in seawater in the three stations is as follows: $\mathrm{Zn}>\mathrm{Pb}>\mathrm{Cd}>\mathrm{Cu}$.

\section{Contents of heavy metals in Ulva}

The heavy metal contents in the Ulva are calculated for the three stations and presented in Table 5.

The concentrations of $\mathrm{Cd}$ and $\mathrm{Zn}$, recorded in Table 5, are significant compared to those found in stations $\mathrm{S} 1, \mathrm{~S} 2$, and S3 $(\mathrm{p}<0.05)$. These concentrations are still important for $\mathrm{Cd}, \mathrm{Pb}$

T a b l e 5. Variations in heavy metals concentrations ( $\mathrm{mg} / \mathrm{kg}$; dry weight) of sea lettuce in the littoral zone of Beni Saf and Honaine harbour, during the period 2011-2012, in all three stations S1, S2 and S3. The results are expressed as mean \pm SE, limit values are in brackets (SE: standard errors).

\begin{tabular}{|l|c|c|c|c|}
\hline & Cd & Pb & Cu & Zn \\
\hline \multirow{2}{*}{ S1 } & $0.12-0.73$ & $0.62-0.91$ & $0.02-0.92$ & $5-60.64$ \\
& $0.36 \pm 0.31$ & $0.62 \pm 0.26$ & $0.54 \pm 0.67$ & $27.81 \pm 28$ \\
\hline \multirow{2}{*}{ S2 } & $0.24-0.66$ & $0.02-0.71$ & $4.3-5.6$ & $35.12-104$ \\
& $0.39 \pm 0.18$ & $0.41 \pm 0.29$ & $4.85 \pm 0.98$ & $29.52 \pm 30$ \\
\hline \multirow{2}{*}{ S3 } & $0.14-0.25$ & $0.03-0.81$ & $1.4-3.4$ & $2-36$ \\
& $0.15 \pm 0.08$ & $0.36 \pm 0.34$ & $2.33 \pm 1.36$ & $12.99 \pm 13$ \\
\hline
\end{tabular}


and $\mathrm{Zn}$ during different seasons. The effect of seasons and stations was proven by the significant result obtained for $\mathrm{Pb}$ only $(\mathrm{p}<0.05)$; however, no significant difference was observed between the stations and seasons $(p<0.001)$. The combined effect of stations and seasons remained significant only for lead.

The concentrations of metals studied in Ulva decrease in the following order: $\mathrm{Zn}>\mathrm{Cu}>$ $\mathrm{Pb}>\mathrm{Cd}$.

The concentration of cadmium (Cd) in Ulva was found between 0.24 and $0.66 \mathrm{mg} / \mathrm{kg}$, with a mean concentration of $0.39 \pm 0.18 \mathrm{mg} / \mathrm{kg}$ dry weight. The average concentration was high in station S2 compared to stations S1 and S3. The average cadmium content bioaccumulated by sea lettuce exceeds the standards of the Mediterranean coastal areas $(0.2 \mathrm{mg} / \mathrm{kg}$ dry weight), as determined by the F.A.O (1994). These figures also indicate that the cadmium levels exceed the official standards of the European Communities (N.O.C.E), which sets a threshold of $0.05 \mathrm{mg} / \mathrm{kg}$ dry weight in algae, edible herbs. Previous works on this species report the same conclusion on the Moroccan coast (Kaimoussi et al., 2004, 2005). The concentrations accumulated in Ulva range from about 0.35 to $1.4 \mathrm{mg} / \mathrm{kg}$ dry weight, with an average of $0.92 \mathrm{mg} / \mathrm{kg}$ dry weight. In Fucus spiralis, the concentration varies from 0.84 to $5.20 \mathrm{mg} / \mathrm{kg}$ dry weight, with an average of $2.41 \mathrm{mg} / \mathrm{kg}$ dry weight. According to the previous works of Stenner and Nikless (1975), it was found that green algae, such as the Fucus sp. can accumulate cadmium with values from 0.8 to $7.4 \mathrm{mg} / \mathrm{kg}$ dry weight; it is $0.8-7.4 \mathrm{mg} / \mathrm{kg}$ dry weight for Enteromorpha sp. and $0.5-4.1 \mathrm{mg} / \mathrm{kg}$ dry weight for Ulva lactuca. The same bioaccumulation effect was noted in some other works about the Italian coast. Indeed, an average cadmium concentration of $0.29 \mathrm{mg} / \mathrm{kg}$ dry weight was reported in the works of Campanella et al. (2001). According to Storelli et al., 2001, this concentration is $0.20 \mathrm{mg} / \mathrm{kg}$ dry weight in U. lactuca; it varies between 0.14 and $0.60 \mathrm{mg} / \mathrm{kg}$. Some recent works by Conti and Finoia (2010) related to Posidonia pavonica indicated that a normal cadmium bioaccumulation between 0.24 and $1.66 \mathrm{mg} / \mathrm{kg}$ dry weight was found on the Italian coastline. Therefore, it is in this reality that sea lettuce can be classified as a bioaccumulator of trace metals; it is the most sensitive species to metal pollution. Sea lettuce is obviously a bioindicator of pollution, especially in the case of cadmium on most Mediterranean coasts (Kaimoussi et al., 2004). Indeed, the studied Ulva sp. shows a cadmium contamination in station S2 in the area of Honaine; this is below the threshold limit requested by the FAO standards and classification (NOC. The bioaccumulated cadmium content may be attributed to the receiving environment.

Lead concentration in Ulva was found between 0.62 and $0.91 \mathrm{mg} / \mathrm{kg}$, with a mean value of $0.62 \pm 0.26 \mathrm{mg} / \mathrm{kg}$ dry weight. The average concentration was found to be high in station S1 as compared to stations S2 and S3. The average content of lead bioaccumulated by our species does not exceed the standards in the Mediterranean coastal areas, as prescribed by FAO which requires a limit of $8.3 \mathrm{mg} / \mathrm{kg}$ dry weight (F.A.O, 1994) The annual average lead content is $0.62 \mathrm{mg} / \mathrm{kg}$ dry weight; it still remains within the standards. Nevertheless, these lead levels are higher than the official European standards, which set a threshold limit of $0.1 \mathrm{mg} / \mathrm{kg}$ dry weight for edible plants.

Stenner and Nickless (1975) conducted a study on the Moroccan, Spanish and Portuguese coasts and found that green algae, such as Fucus sp., can accumulate lead between 5 and $13 \mathrm{mg} / \mathrm{kg}$ dry weight. It can be between 4 and $22 \mathrm{mg} / \mathrm{kg}$ dry weight in Enteromorpha sp. 
and can go up to $10 \mathrm{mg} / \mathrm{kg}$ dry weight in Ulva lactuca. More recently, Storelli et al. (2001) have led some works about the Italian coasts; they indicated that the average concentrations are much lower than $0.84 \mathrm{mg} / \mathrm{kg}$ dry weight in Ulva. According to Conti and Finoia (2010), lead concentrations are set between 1.43 and $7.44 \mathrm{mg} / \mathrm{kg}$ dry weight in algae Posidonia pavonica. However, according to Campanella et al. (2001), the average lead concentration is equal to $14.7 \mathrm{mg} / \mathrm{kg}$ dry weight in sea lettuce. From these results, this species Ulva lactuca can be considered as a pollution bioindicator on the Mediterranean coast (Brown et al., 1999) The studied species shows lead contamination in station S1 in the region of Beni Saf, according to standards (NOCE).

The concentration of copper $(\mathrm{Cu})$ in Ulva was found between 4.35 and $5.86 \mathrm{mg} / \mathrm{kg}$, with an average concentration of $4.85 \pm 0.98 \mathrm{mg} / \mathrm{kg}$ dry weight. The average concentration was higher in station S2 compared to stations S1 and S3. The average bioaccumulated copper content in this actual species did not exceed the standards on the Mediterranean coastal areas, as required by the FAO, with a level of $6.9 \mathrm{mg} / \mathrm{kg}$ dry weight. Previous works on this same species reported the same observation on the Moroccan coast. According to Kaimoussi et al. $(2004,2005)$, the concentrations accumulated in Ulva vary from 5.5 to $21.5 \mathrm{mg} / \mathrm{kg}$ dry weight, with an average concentration of $14.5 \mathrm{mg} / \mathrm{kg}$ dry weight. In Fucus spiralis, concentrations between 4.1 and $11.5 \mathrm{mg} / \mathrm{kg}$ dry weight, with an average concentration of $6.1 \mathrm{mg} / \mathrm{kg}$ dry weight, have been reported. In a study on the Spanish coast, Stenner and Nikless (1975) found that green algae, such as Ulva lactuca, can accumulate copper with concentrations ranging from 5.5 to $31 \mathrm{mg} / \mathrm{kg}$ dry weight. It is worth mentioning that the species under study was not found to be contaminated by copper in the stations; they were not affected by this metal throughout the seasons.

However, the receiving environment was contaminated with copper, but this has clearly not affected the species studied (Shiber, Washburn, 1978). Seasonal fluctuations of metal concentrations in algae were often observed (Pohl et al., 1993). However, the growth activities alone are not responsible for the difference in the seasonal variations between metals. These variations could also result from the temporal changes of metal contents in the surrounding seawater (Phillips, 1994). Metal content in marine macro-algae is generally low during the warm months, because of the high growth rates, which 'dilute' the accumulated metals (Pohl et al.,1993). However, Hägerhäll (1973) announced that copper and zinc contents in Ascophyllum nodosum in Öresund (Sweden) were at their maximum in mid-July. Drude De Lacerda and Teixeira (1985) found that concentrations of Cd, Cu and $\mathrm{Pb}$ (amongst other metals) in five marine algae (sampling site in southern Brazil) were generally at their highest in January (summer) and at their minimum in August (winter). Similarly, Fernanda Leal et al. (1997) found that the levels of $\mathrm{Cd}$, and $\mathrm{Pb}$ in both Enteromorpha sp. and Porphyra sp. were higher in the spring season (June-April) and winter (March-November). Some authors (Conti, Finoia, 2010) studied the seasonal variation of bioaccumulation of copper; they recorded almost identical models, with minimums in winter, probably because they have similar seasonal demand in metal enzymes containing copper (Sawidis, Voulgaropoulos, 1986). For other authors, the content of heavy metals in algae depends on the age of these same algae. Indeed, Forsberg et al. (1988) noted that the concentration of metals (Al, Co, $\mathrm{Fe}, \mathrm{Mn}, \mathrm{Ni}$ and $\mathrm{Zn}$ ) in older thalli, which exceeded that in the growing ones, such as Fucus 
vesiculosus. In the case of sea lettuce, copper demand is much higher in the warm periods. This is well noted in station S2 in the area of Honaine.

The concentration of zinc (Zn) in Ulva is between 35.12 and $104 \mathrm{mg} / \mathrm{kg}$, with an average concentration of $29.52 \pm 30 \mathrm{mg} / \mathrm{kg}$ dry weight. The average concentration is higher in station $\mathrm{S} 1$ compared to stations $\mathrm{S} 2$ and $\mathrm{S} 3$. The average zinc content bioaccumulated by our species is slightly higher than the standards of the Mediterranean coastal areas, as required by FAO, for which the limit is set to $24.8 \mathrm{mg} / \mathrm{kg}$ dry weight (FAO, 1994). Stenner and Nickless (1975) led some works on the Moroccan, Spanish and Portuguese coasts and found out that green algae can accumulate zinc from 75 to $130 \mathrm{mg} / \mathrm{kg}$ dry weight in Enteromorpha sp. and from 37.2 to $116.5 \mathrm{mg} / \mathrm{kg}$ dry weight in algae. According to Fuge and James (1974), Fucus vesiculosus can, however, accumulate between 72.1 and $330.5 \mathrm{mg} / \mathrm{kg}$ dry weight . More recently, Storelli et al. (2010) have carried out investigations on Italian coasts and reported some average concentrations that exceed $127.27 \mathrm{mg} / \mathrm{kg}$ dry weight in Ulva. This concentration was found to vary between 34.39 and $192.17 \mathrm{mg} / \mathrm{kg}$ dry weight. On the other hand, according to Conti and Finoia (2010), zinc concentrations range from 29.1 to $67.7 \mathrm{mg} / \mathrm{kg}$ dry weight in algae Posidonia pavonica. According to the work of Campanella et al. (2001), the average zinc concentrations are set to $50 \mathrm{mg} / \mathrm{kg}$ dry weight in sea lettuce. Kaimoussi et al. (2004) conducted studies on the Moroccan coasts and noted much higher concentrations in Ulva lactuca, which can accumulate between 96 and $306 \mathrm{mg} / \mathrm{kg}$ dry weight, with an average concentration of $163 \mathrm{mg} /$ $\mathrm{kg}$ dry weight.

According to some studies carried on the Mediterranean coast, the species U. lactuca can be classified as a bioindicator for zinc pollution (Brown et al., 1999). The species studied showed zinc contamination in station S2 in the area of Honaine; station S1 in the region of Beni Saf, and a slight contamination in station S3 in the port area of Honaine (FAO, 1994).

- The metal concentrations observed in sea lettuce U. lactuca in both coastal areas of Beni Saf and Honaine did not show excessively high levels to present a risk of contamination. Nevertheless, cadmium and lead, which are considered as toxic metals and belong to the class of toxic metals, could be detected because they were found at levels higher than those required by FAO standards (1994) and by the European Communities NOCE (2001). Therefore, U. lactuca was effectively contaminated with lead in the port of Beni Saf (S1) and slightly contaminated in the port of Honaine (S3); it also contained some cadmium in the coastal region of Honaine (S2). Amongst the metals that are essential to the formation of coastal algae, zinc seems to be more abundant than copper. Comparing our data with those from the literature, for the same species collected in polluted or unpolluted areas, shows that the concentrations of $\mathrm{Cd}$ and $\mathrm{Cu}$ are intermediate between the limits given in the literature, although, in many cases, these levels show lower values than those found in other geographic areas (Munda, Hudnik, 1991; Seeliger, Edwards, 1987; Stenner, Nickless, 1975; Dumon et al., 1994; Güven et al., 1993). Thus, the studied species was slightly contaminated with zinc in most of the three stations, S1, S2 and S3, particularly in the port of Beni Saf. Obviously, this is probably due at first to the species' needs to bioaccumulate zinc, which is $10-100 \mathrm{mg} / \mathrm{kg}$ dry weight of the species' needs to produce its chlorophyll and to grow. In other studies, Rodica et al. (2006) revealed average concentrations of zinc $(32.8 \mathrm{mg} / \mathrm{kg}$ dry weight), copper $(9.4 \mathrm{mg} / \mathrm{g}$ dry matter of copper) and lead ( $4 \mathrm{mg} / \mathrm{g}$ dry weight) in $U$. rigida in Romania. The value found 

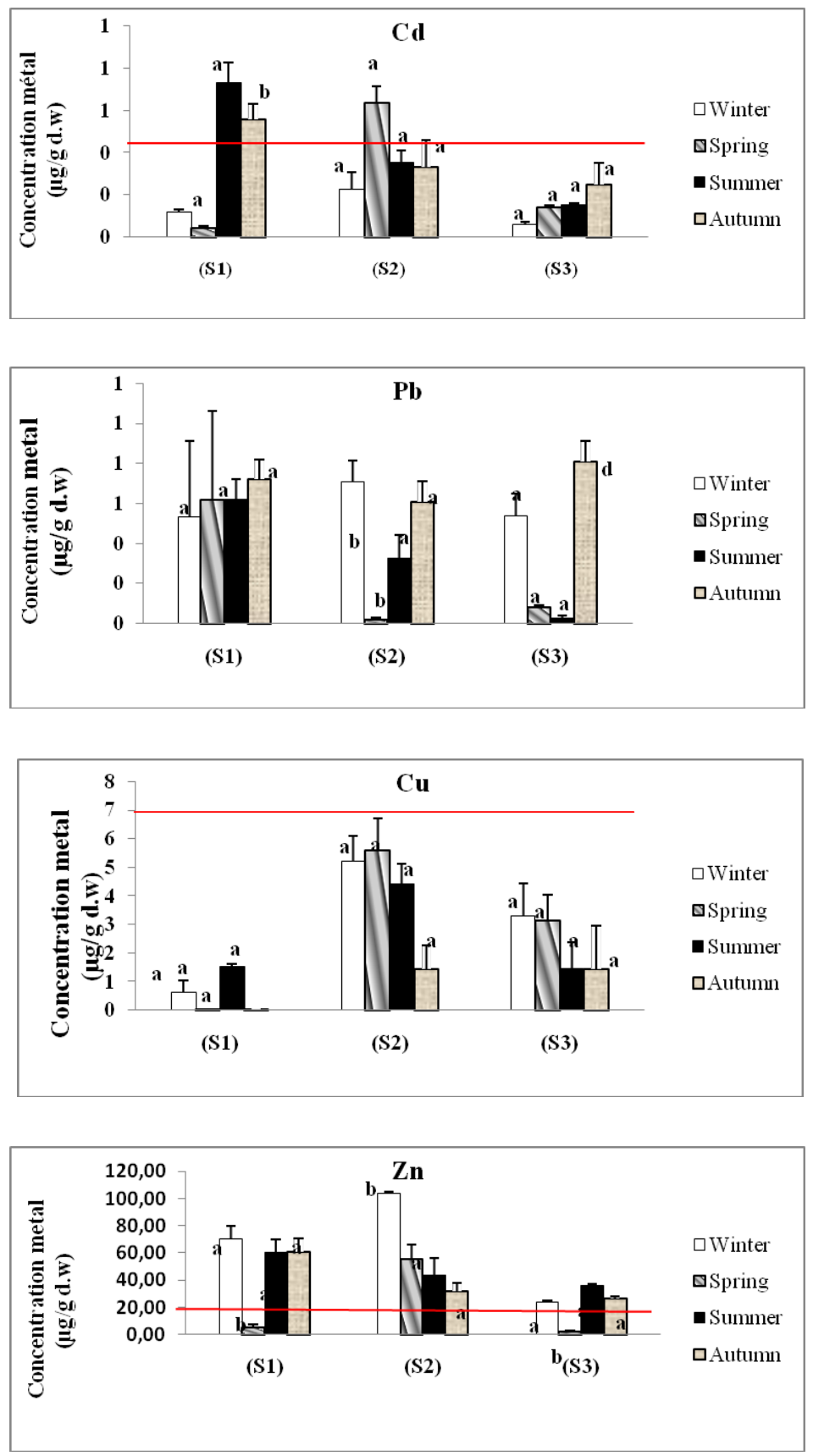

Fig. 3. Seasonal variations in the metal concentrations ( $\mathrm{Cd}, \mathrm{Pb}, \mathrm{Cu}$ and $\mathrm{Zn}$ ) in $\mathrm{mg} / \mathrm{kg}$ (dry weight) in sea lettuce Ulva lactuca levied at the two coastal areas of Beni Saf and Honaine in (western Algerian coast). 
for zinc was $2-16 \mathrm{mg} / \mathrm{kg}$ dry weight in $100 \mathrm{~g}$ dry weight in Ulva in Morocco (F.E.N.I.P, 2015). In addition, considering the French Standards, food marine plants require less than $5 \mathrm{mg} / \mathrm{kg}$ of lead and less than $0.5 \mathrm{mg} / \mathrm{kg}$ of cadmium (Perez, 1997).

\section{Conclusion}

The study of the four heavy metals $(\mathrm{Cd}, \mathrm{Pb}, \mathrm{Cu}$ and $\mathrm{Zn})$ in sea lettuce Ulva lactuca on the western coastlines of Beni Saf and Honaine showed that their concentrations vary with the sampling site and the season (Fig. 3). The heavy metal levels generally increase from winter to summer. Except for cadmium, the highest heavy metal concentrations were detected in station S2, which receives the discharges of urban waste water from the town of Ouled Youcef (collector C2). However, it was noted that the species under study in the coast areas of Beni Saf and Honaine was very slightly contaminated by Copper $(\mathrm{Cu})$. The concentrations of $\mathrm{Zn}$ in the same species were found to be significant. The accumulation of heavy metals generally follows this order: $\mathrm{Zn}>\mathrm{Cu}>\mathrm{Pb}>\mathrm{Cd}$ (Nouri, Haddioui, 2016).

The presence of heavy metals in algae on the coasts of Beni Saf and Honaine is lower than that recorded in other parts of the world. With the urban intensification and port activities, the heavy metal levels will continue to increase, and, consequently, the purification of waste waters by a suitable treatment plant system becomes necessary if one wants to preserve the aquatic ecosystem balance in these regions, which may be in danger in the coming years. It is recognised that marine algae have therapeutic properties and can provide nutritional virtues to humans.

Algae can provide a balanced diet, proper prevention of lifestyle-related diseases and better health conditions in many areas. Thanks to the modern techniques of preparation, preservation and packaging, algae are now within the reach of all. It is necessary to develop and take advantage of these potential concentrates for our health and beauty. Therefore, algae, in general, and particularly those belonging to the algal Class of Chlorophyceae, which contains Ulva, have a huge medical, pharmaceutical and cosmetic potential; they have a significant impact on the economy, food industry and so on.

\section{Acknowledgements}

The authors would like to thank the laboratory of Separation and Purification Technologies at the University of Tlemcen in Algeria and the Department of Chemical Engineering and Environment, the High Technical School of Engineering at the University of Seville in Spain, for their financial support.

\section{References}

Aminot, A. \& Chaussepied M. (1983). Manuel des analyses chimiques en milieu marin. CNEXO.

Bagnouls, F. \& Gaussen J. (1953). Saisons sèches et indice xérothermique. Bull. Soc. Hist. Nat. Toulouse, 88(3-4), 139-239.

Brown, M.T., Hodgkinson, W.M. \& Hurd C.L. (1999). Spatial and temporal variations in the copper and zinc concentrations of two green seaweeds from Otago Harbour, New Zealand. Mar. Environ. Res., 47, 175-184. DOI : 10.1016/S0141-1136(98)00113-5.

Bryan, G.W. \& Hummestrone L.G. (1973) .Brown seaweed as on indicator of heavy metals in estuaries of south west England. J. Mar. Biol. Assoc. UK, 53, 705-720. DOI: 10.1017/S0025315400058902. 
Campanella, L., Conti, M.E., Cubadda, F. \& Sucapane C. (2001). Trace metals in sea grass, algae and mollusks from an uncontaminated area in the Mediterranean. Environ. Pollut., 111, 117-126. DOI: 10.1016/S02697491(99)00327-9.

Cheggour, M., Chafik, A., Langston, W.J., Burt, G.R., Benbrahim, S. \& Texier H. (2001). Metals in sediments and the edible cokle Cerastooder maedule from two Moroccan Atlantic lagoons: Moulay Bouselham and Sidi Moussa. Environ. Pollut., 115, 149-160. DOI : 10.1016/S0269-7491(01)00117-8.

Conti, M.E. \& Finoia M.G. (2010). Metals in molluscs and algae: A north-south Tyrrhenian Sea baseline. J. Hazard. Mater., 181, 388-392. DOI: 10.1016/j.jhazmat.2010.05.022.

De Villers, J., Squilbin, M. \& Yourassowsky C. (2005). Qualité physico-chimique et chimique des eaux de surface: cadre général. Fiche 2, Institut Bruxellois «IBGE » pour la gestion de l'environnement/observatoire des données de l'environnement.

Drude de Lacerda, L. \& Teixeira J.R.D. (1985). Guimaraes, Seasonal variation of heavy metals in seaweeds from Conceiçao de Jacarei (R.J.) Brasil. Bot. Mar., 28, 339-343.

Dumon, J.-C., Lapaquellerie, Y. \& Latouche C. (1994). Éléments-traces des algues et des phanérogames marines (Zostères) du contexte laguno-marin d'Arcachon. Recherche des influences de l'environnement pédologique sur le chimisme du peuplement végétal. Vie Milieu, 44(3/4), 167-183.

F.A.O. (1994). Etude des métaux lourds présents dans l'environnement aquatique Africain. Département de la pêche, Doc. Technique CPCA. NO. 25. Rome.

F.E.N.I.P. (2015). Fédération Nationale des Industries de Transformation des Produits de la Pêche, Voies de valorisation des produits Marocains de la mer: http://www.fenip.com/upload/documentation/valorisation p02.pdf.

Fernanda Leal, M.C., Vasconcelos, T., Sousapinto, M.I. \& Cabral J.P.S. (1997). Biomonitoring with benthic Macroseaweed and direct assay of heavy metals in seawater of the oporto coast (Northwest Portugal). Mar. Pollut. Bull., 34(12), 1006-1015. DOI: 10.1016/S0025-326X(97)00112-4.

Flament, M. (2010). Action distribution directe. Rev. Related Research, Entreprise Avenue du Parc : agrée par la DRAAF-SRAL-PICARDIE, Passel, France.

Forsberg, A., Söderlund, S., Frank, A., Peterson, L.R. \& Pedersen M. (1988). Studies on metal content in the brown seaweed, Fucusvesi culosus, from the Archipelago of Stockholm. Environ. Pollut., 49, 245-263. DOI: 10.1016/0269-7491(88)90091-7.

Fuge, R.K. \& James H. (1974). Traces metals concentrations in Fucus from the Bristol Chanel. Mar. Pollut. Bull., 5(1), 9-12. DOI:10.1016/0025-326X(74)90026-5.

Güven, K.C., Saygi, N. \& Öztürk B. (1993). Survey of metal contents of Bosphorus seaweed, Zostera marina and sediments. Bot. Mar., 36, 175-178.

Hägerhäll, B. (1973). Marine botanical-hydrographical trace element studies in the Öresund Area. Bot. Mar., 16, 53-64.

Ho, Y.B. (1987). Metals in 19 intertidal macro seaweed in Hong Kong waters. Mar. Pollut. Bull., 18, 564-566. DOI: 10.1016/0025-326X(87)90542-X.

Ho, Y.B. (1990). Metals in Ulva lactuca in Hong Kong intertidal waters. Bull. Mar. Sci., 47, 79-85.

Huppatzet, W. \& Meissner H. (1987). Effect of the temperature and salt content of sea water on the corrosion behaviour of aluminium. Werkstoffe und Korrosion, 38, 709-710.

J.O.R.A (Journal Official of Algerian republic) (2006). Normes de valeurs limites des paramètres de rejet dans un milieu récepteur. Algérie.

Kaimoussi, A., Mouzdahir, A. \& Saih A. (2004). Variations saisonnière des teneurs en métaux (Cd, Cu, Fe, Mn et Zn) chez l'algue Ulva lactuca prélevée au niveau du littoral de la ville d'El Jadida (Maroc). C.R. Biol., 327, 361-369. DOI: 10.1016/j.crvi.2004.01.007.

Kaimoussi, A., Mouzdahir, A. \& Saih A. (2005). Variations saisonnière des concentrations en métaux (Cd, Cu, Fe, $\mathrm{Mn}$ et $\mathrm{Zn}$ ) chez l'algue Ficus spiralis du littoral de la ville d'El Jadida (Maroc). Water Qual. Res. J. Can., 40(1), 102-110. DOI: 10.2166/wqri.2005.010.

Leynaud, G. (1968). Les pollutions thermiques, influence de la température sur la vie aquatique. B.T.I. Ministère de l'agriculture, 224-881.

MacArtain, G., Gill, Ch.I.R., Brooks, M., Campbell, R. \& Rowland I.R. (2007). Nutritional value of edible seaweeds. Nutrition Reviews, 65, 535-543. DOI: 10.1111/j.1753-4887.2007.tb00278.x.

Marcet, A.P. (1919). Trans. Royal Society, 206, 161.

Martin, J. \& Whitfield M. (1983). The significance of river input of chemical elements to the Ocean. In C.S. Wong \& E. Boyle (Eds.), Trace metals in sea water (pp. 265-296). New York: Plenum Press. 
Munda, I.M., Hudnik V. (1991). Trace metal content in some seaweed from the Northern Adriatic. Bot. Mar., 34, 241-249.

Nakhlé, F.K. (2003). Le mercure, le cadmium et le plomb dans les eaux littoral libanaises : Apports et suivi au moyen de bioindicateurs qualitatifs (Eponge, bivalve et gastéropodes). Thèse. Spécialité : Interactions toxiques dans les écosystèmes, Paris.

Nouri, A . \& Haddioui A. (2016). Assessment of metals contamination and ecological risk in ait Ammar abandoned iron mine soil, Morocco. Ekológia (Bratislava), 35(1), 32-49. DOI: 10.1515/eko-2016-0003.

O.I.E.( 2009). Office International de l'eau, indicateur de qualité. REFEA, France.

Pastor, A., Hernandez, F., Peris, M.A., Beltran, J., Sancho, J.V. \& Castillon M.T. (1994). Levels heavy metals in some marine organisms from the western Mediterranean area (Spain). Marine Pollution Bull., 28(1), 50-53. DOI: 10.1016/0025-326X(94)90186-4.

Perez, R. (1997). Ces algues qui nous entourent. Plouzane: IFREMER.

Phillips, D.J.H. (1994). Macrophytes as biomonitors of trace metals. In K.J.M. Kramer (Ed.), Biomonitoring of coastal waters and estuaries (pp. 85-103). Boca Raton: CRC Press.

Poggi, R. (1990). Impacts sanitaires des contaminations microbiologiques. In J.F. Guillaud \& L.A. Romana (Eds.), La mer et les rejets urbains (pp.115-132).

Pohl, C., Kattner, G. \& Schulz M. (1993). Blades, cadmium, copper, lead and zinc on transects through Arctic and Eastern Atlantic surface and deep waters. J. Mar. Syst., 4, 17-29. DOI: 10.1016/0924- 7963(93)90017-G.

Rodica, S., Constanta, S., Lucia G.D. \& Passy N. (2006). Caractérisation de certains principes actifs de Ulva lactuca et Ulva rigida : Algues vertes du littoral roumain de la mer noire. Scientific Study and Research, 7(1), 193-198.

Rodier, J. (1984). Lanalyse de l'eau : Eaux naturelles, eaux résiduaires, eaux de mer. Paris: Dunod.

Sawidis, T. \& Voulgaropoulos A.N. (1986). Seasonal bioaccumulation of iron, cobalt and copper in marine seaweed from thermaikos gulf of the northern Aegean sea, Greece. Mar. Environ. Res., 19, 39-47. DOI: 10.1016/01411136(86)90038-3.

Seeliger, U. \& Edwards P. (1987). Correlation coefficients and concentration factors of copper and lead in seawater and benthic seaweed. Mar. Pollut. Bull., 8, 16-19. DOI: 10.1016/0025-326X(77)90398-8.

Shiber, J.G. \& Washburn A. (1978). Lead, mercury and certain nutrient elements in Ulva lactuca (Linnaeus) from Ras Beirut, Lebanon. Hydrobiology, 61, 187-192. DOI: 10.1007/BF00018750.

Stenner, R.D. \& Nickless G. (1975). Heavy metal in organisms of the Atlantic coast of SW Spain and Portugal. Mar. Pollut. Bull., 6, 89-92. DOI: 10.1016/0025-326X(75)90151-4.

Storelli, M.M, Storelli, A. \& Macrotrigiano G.O. (2001). Heavy metals in the aquatic environment of the Southern Adriatic Sea, Italy macroalgae, sediment and benthic species. Environ. Int., 26, 505-509. DOI: 10.1016/S01604120(01)00034-4.

Taleb, M.Z. \& Boutiba Z. (2007). La moule Mitillusgallo provinciallis bioindicatrice de pollution marine - cas du port d'Oran. Sciences et Technologie C, 25, 59-64.

Usero, J., Izquierdo, C., Morillo, J. \& Gracia I. (2003). Heavy metals in fish (Solea vulgaris, Anguilla anguilla and Liza aurata) from salt marshes on the southern Atlantic coast of Spain. Environ. Int., 29, 949-956. DOI: 10.1016/ S0160-4120(03)00061-8.

W.H.O. (1987). Global pollution and health results of related environmental monitoring. Global environment monitoring system. WHO, UNEP.

Wong, M.H., Kowk, T.T. \& Ho K.C. (1982). Heavy metals in Ulva lactuca collected within Tolo + Harbour, an almost land locked sea. Hydrobiological Bulletin, 16, 223-230. DOI: 10.1007/BF02255376. 